\title{
DESCRIPTION OF ENDOTHENIA APOTOMISANA SP. N. AND CYDIA PELIONAE SP. N. FROM PELION MOUNTAINS, GREECE (LEPIDOPTERA TORTRICIDAE)
}

\author{
(*) Department of Agricultural, Environmental and Food Sciences, University of Molise, Campobasso, Italy \\ ( ${ }^{\circ}$ Corresponding author: trema@unimol.it \\ Trematerra P., Colacci M. - Description of Endothenia apotomisana sp. n. and Cydia pelionae sp. n. from Pelion \\ Mountains, Greece (Lepidoptera Tortricidae). \\ Two species of Lepidoptera Tortricidae Olethreutinae: Endothenia apotomisana sp. n. and Cydia pelionae sp. n., \\ collected in Greece (Thessaly) on Pelion Mountain's, are described as new to science.
}

KeY Words: Lepidoptera, Tortricidae, Endothenia apotomisana, Cydia pelionae, new species, Greece.

\section{INTRODUCTION}

In the present work Endothenia apotomisana sp. n. (Tortricidae Olethreutinae Olethreutini) and Cydia pelionae sp. n. (Tortricidae Olethreutinae Grapholitini) are described as new to science, according to available literature (MEYRICK, 1912; KuZNETSOV, 1962, 1989; RAZOWSKI, 2003; AARVIK, 2013).

The Lepidoptera Tortricidae from Greece have received only sporadic attention by both local and foreign lepidopterists with publications referring to one or few entities (for example AARVIK and KARSHOLT, 1993; TrEmaterra and KARShOlt, 1996; TREMATERRA and AARVIK, 1998; BASSI, 2014; HuEMER, 2016), while lacking summary works that consider the Hellenic fauna as a whole (GOZMANY, 2012).

Our materials were collected on the Pelion Mountains (Magnisia, Greece) in the para-Mediterranean broad-leaved deciduous trees zone (Quercetalia pubescentis); this zone includes Oak forests (Quercus frainetto) and Chestnut forests (Castanea sativa).

\section{Endothenia apotomisana sp. n.}

\section{MATERIAL EXAMINED}

Holotype, 1 male, Greece - Magnisia, Pelion, Drakia, 980 m, 6.IV.2016, 39.378178, $23.029793^{\circ}$, M. Colacci and C. Rumbos legit. (Collection Trematerra, Campobasso, Italy).

\section{DESCRIPTION}

Adult. Wingspan $14 \mathrm{~mm}$ (Fig. I, 1). Head and thorax dark brown, labial palp brownish. Ground colour of distal half of forewing whitish with weak brownish grey shades, fasciae and submedian interfascia suffused with brownish grey, more whitish in dorsal portion, with brownish grey lines; costal strigulae brown; markings brownish grey with more brown, distinct transverse lines, with diffused basal blotches; dark brown median fascia; terminal markings weaker, rusty; tornal blotch brownish-grey; cilia brown and brownish-grey, relatively concolorous with wing markings and whitish basally. Hindwing light brown, mixed browngrey distally; cilia paler, brownish basally.

Male genitalia (Fig. I, 2-10). Uncus curved with broad terminal part, slightly convex, equipped with several spines and hairs (Fig. I, 4 and 5); socius broad, rounded, subtriangular, with long hairs (Fig. I, 6); tegumen broad; short sacculus with spiny lobe (Fig. I, 3); internal side of basal cavity of valva, below spiny lobe, presents a thorny formation plume shaped (Fig. I, 8, 9 and 10); cucullus spined ventrally, medially slender, slightly expanded in the distal part, rounded at apex (Fig. I, 2); saccus slightly pronounced; aedeagus broad, cornutus absent (Fig. I, 7).

Female genitalia. Unknown

\section{DISTRIBUTION}

Known only for the locus typus: Pelion, Drakia (Thessaly, Magnisia, Greece).

\section{BIOLOGY}

Moth collected with net in early April. Food plants are unknown.

\section{DiAGNOSIS}

E. apotomisana joins the characters of Apotomis Hübner and mostly Endothenia Stephens. The basal cavity of valvae have a thorny formation extending from the outer side of the outer surface of the valva which is unknown within the family (RAzOwSKI, 1989). The valvae lobe is typical of Apotomis at first sight (RAzOwSKI, 2003). There are no external differing characteristics between the species of the two genera.

\section{ETHYMOLOGY \\ This species is named after the genus Apotomis.}

\section{Cydia pelionae sp. $\mathrm{n}$.}

\section{Material EXAmined}

Holotypes, 1 male, Greece - Magnisia, Pelion, Portaria, 1000 m, 8.VI.2016, 39.383714 ${ }^{\circ}, 23.025592^{\circ}$, M. Colacci 

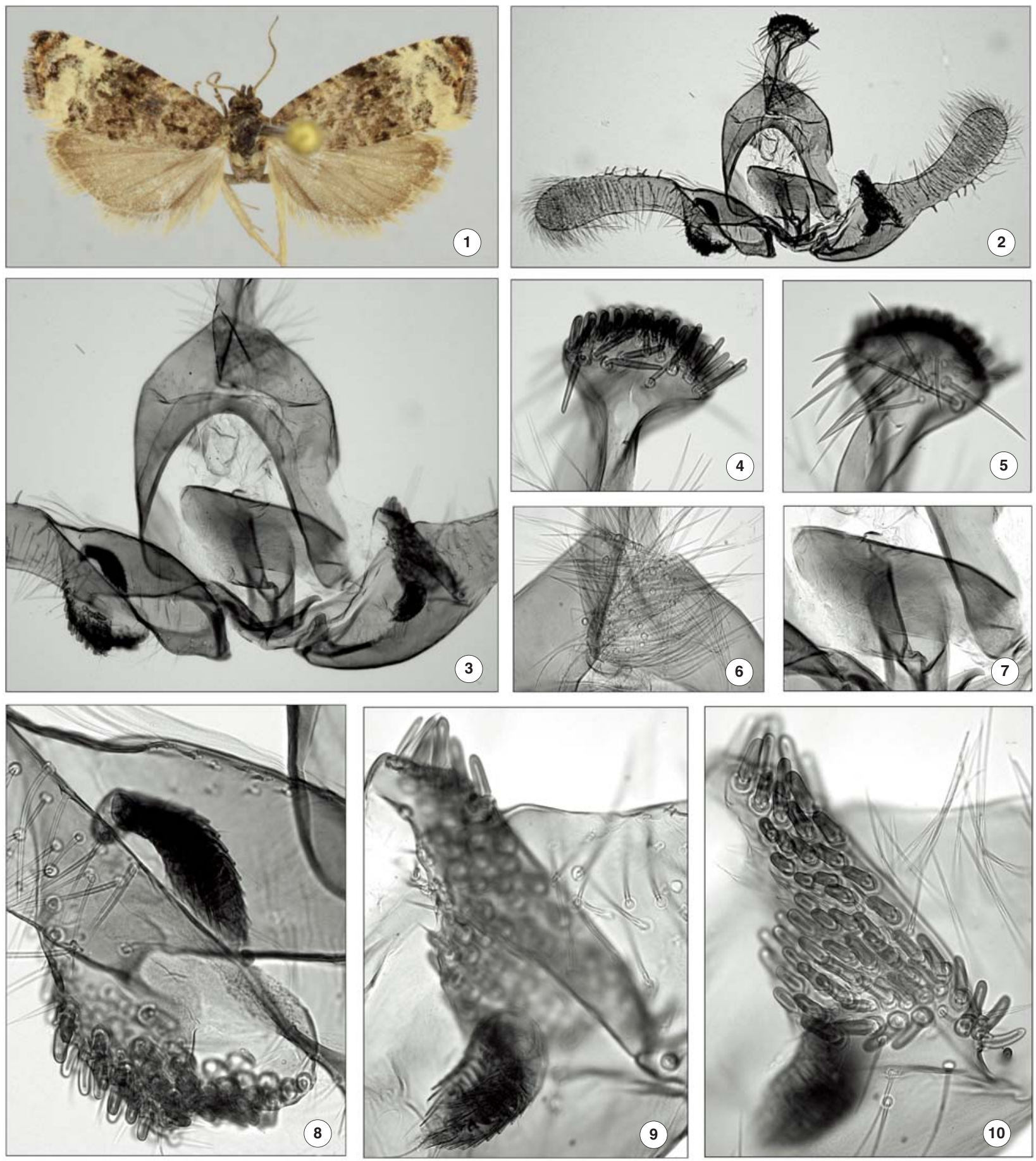

Fig. I - Endothenia apotomiana sp. n., holotype: adult (1); general view of male genitalia (2). Details of male genitalia (3): uncus $(4,5)$; gnathos $(6)$; aedeagus $(7)$; spiny lobe of sacculus and thorny formation: thorny formation on left side (8), thorny formation at different depths on the right side $(9,10)$.

legit; 1 female, Greece - Magnisia, Pelion, Portaria, 1000 $\mathrm{m}, 17$. VI.2016, 39.383714 ${ }^{\circ}, 23.025592^{\circ}$, M. Colacci legit. Paratypes, 1 male, Greece - Magnisia, Pelion, Chania, 1150 $\mathrm{m}, 17 . \mathrm{V} .2016,39.393695^{\circ}, 23.045711^{\circ}$, M. Colacci legit; 2 males, Greece - Magnisia, Pelion, Chania, $1150 \mathrm{~m}$, 15.VI.2016, 39.393695, $23.045711^{\circ}$, M. Colacci legit; 1 male and 1 female, Greece - Magnisia, Pelion, Portaria, 1000 m, 17.VI.2016, 39.383714 ${ }^{\circ} 23.025592^{\circ}$, M. Colacci legit. (Collection Trematerra, Campobasso, Italy).

\section{DESCRIPTION}

Adult (Fig. II, 1). Head and palps light brown. Wing span 12-13 mm (male), 14-15 mm (female). White ground colour of forewing preserved as submedian interfascia, broader in dorsal than in costal half, slightly marked grey dorsally in the middle; basal area of wing creamy brown with browner strigulae and dark brown distal portion, concolorous median fascia; distal half of wing ochreous rust-brown, with distinct refractive markings; white patch divided with brown costal strigulae; speculum ochre-brown with inner spots and well 

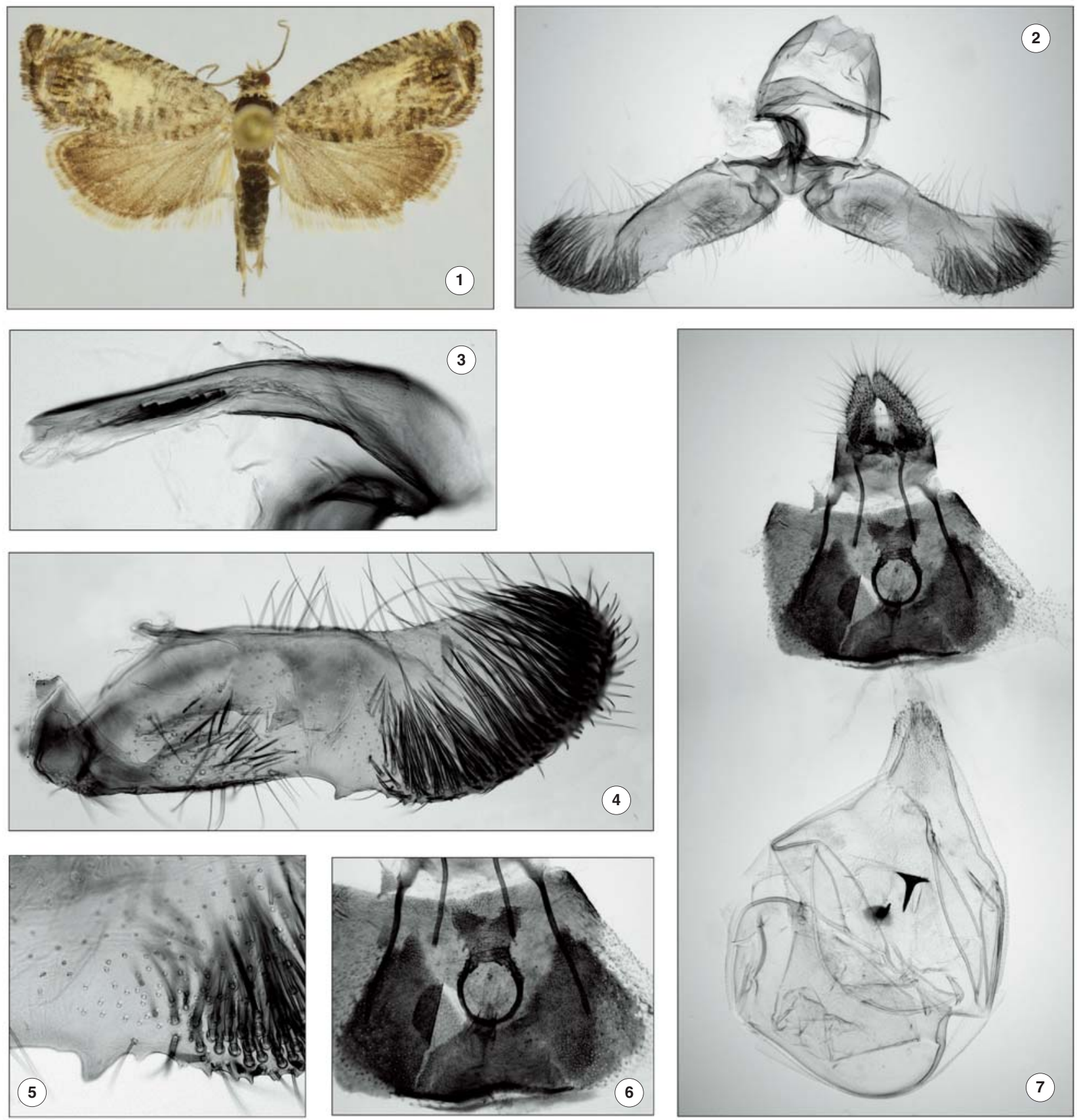

Fig. II - Cydia pelionae sp. n., holotype: adult (1); general view of male genitalia (2). Details of male genitalia: aedeagus (3); valva (4); spiny lobe of sacculus (5). General view of female genitalia (7); detail of antrum, lamella postvaginalis and subgenital sternite (6).

developed lines; outer line of speculum grey; basal fascia dark brown. Cilia brownish. Hindwing brownish, paler basally, darker on periphery; cilia light brown.

Male genitalia (Fig. II, 2-5). Developed tegum (Fig. II, 2); long valvae with concave costal margin (Fig. II, 4); cucullus with rounded apex; sacculus developed; caudal angle of sacculus broad; valvae neck weakly developed; ventral incision slightly rounded; cucullus slender, spined and with small ventro-anterior prominences (Fig. II, 5); basal cavity of valva small; aedeagus simple and slender, posteriorly tapering, without dorso-postmedian formation; cornutus with seven small spines (Fig. II, 3).

Female genitalia (Fig. II, 6 and 7). Sterigma rounded, forming a ring around ostium bursae, with an elongated, relatively slender postostial part expanding posteriorly (Fig. II, 7); subgenital sternite relatively weakly sclerotized (Fig. II, 6); colliculum membranous; ductus bursae fairly long with traces of sclerite beyond base; corpus bursae broad; signa small.

\section{DISTRIBUTION}

Known only from the type locality.

\section{Biology}

Our specimens were collected with net on Pelion Mountain's (Greece) during May and June. Food plants are unknown. 


\section{DiAgNOSIS}

Externally Cydia pelionae is similar to other species in the succedana group, but it differs in male genitalia by the caudal angle of the sacculus, by the small prominences between sacculus and cucullus and by aedeagus without a dorso-postmedian process (DANILEVSKY and KUZNETSOV, 1968). The female genitalia differ by sterigma around the ostium bursae, and by an elongated, relatively slender postostial part expanding posteriorly.

\section{ETHYMOLOGY}

The name is derived from the type locality in Pelion Mountains.

\section{ACKNOWLEDGEMENTS}

We are most grateful to prof. Christos Athanassiou (University of Thessaly, Volos, Greece) and to prof. Jozef Razowski (Polish Academy of Science, Krakow, Poland) for information, comments and helpful suggestions.

\section{REFERENCES}

AARVIK L.E., 2013 - Tortricidae. In: Fauna Europaea: Lepidoptera, Moths, cur. O. KARShOLT \& E.J. VAN Nieukerken. Fauna Europaea version 2.6.2, http://www.faunaeur.org

AARVIK L.E., KARShOLT O., 1993 - New and little known Grapholitini (Lepidoptera, Tortricidae) from Mediterranean area. - Nota Lepidopterologica, 15 (3/4): 164-178.

BASSI G., 2014 - A new species of Ceratoxanthis Razowski, 1960 from Greece (Lepidoptera: Tortricidae, Tortricinae,
Cochylini). - SHILAP Revista de Lepidopterologia, 42 (167): 489-492.

Danilevsky A.S., KuZNetsov V.I., 1968 - Listovertki (Tortricidae). Triba plodozhorki (Laspeiresiini). Fauna SSSR, Nasekomye Cheshuekrylye, Leningrad, 5 (1): 1636.

GoZMANy L., 2012 - The Lepidoptera of Greece and Cyprus. Vol. 1. Pemberley Natural History Books BA, Inver, UK: 1-409.

Huemer P., 2016 - Beitrag zur Wicklerfauna Kretas aus Aufsammlungen von Dr. Walter Ruckdeschel (Lepidoptera, Tortricidae). - Nachrichtenblatt der Bayerischen Entomologen, 65 (1/2): 2-12.

KuZnetsov V.I., 1962 - Neue Palaearktische Arten der Gattung Laspeyresia Hb. (Lepidoptera, Tortricidae). Entomological Review, 41: 627-642.

KuZNETSOV V.I., 1989 - Family Tortricidae (Olethreutidae, Cochylidae) - Tortricid Moths. In: Medvedev G.S., Keys to the insects of the European Part of the USSR, Volume IV, Lepidoptera, Part I. - E.J. Brill, Leiden: 279-991.

MeYrICK E., 1912 - Exotic Microlepidoptera, I: 1-640.

Razowski J., 1989 - The Genera of Tortricidae (Lepidoptera). Pert II: Palaearctic Olethreutinae. - Acta Zoologica Cracoviensia, 32 (7): 107-328.

Razowski J., 2003 - Tortricidae of Europe. Volume 2. Olethreutinae. - Frantisek Slamka, Bratislava: 1-301.

Trematerra P., AARVIK L.E., 1998 - Reperimento di Cydia johanssoni Aarvik \& Karsholt, 1993, (Lepidoptera Tortricidae) in Italia e descrizione della femmina. Bollettino di Zoologia agraria e Bachicoltura, Ser. II, 30 (1): 33-38.

Trematerra P., Karsholt O., 1996 - New records of Tortricidae for Greek and Spanish fauna (Lepidoptera Tortricidae). - Bollettino di Zoologia agraria e Bachicoltura, Ser. II (2): 141-147. 